\title{
Customer Perceived Value Towards Convenience Stores in Malaysia: The Influence on Customer Satisfaction, Loyalty and Retention
}

\author{
Abdulrauf Animashaun \\ Lord Ashcroft International Business School, FTMS Malaysia Center \\ Anglia Ruskin University \\ Tarila Iman Tunkarimu \\ Lord Ashcroft International Business School, FTMS Malaysia Center \\ Anglia Ruskin University \\ Omkar Dastane ${ }^{1}$ \\ Head - Centre for Postgraduate Studies cum Senior Lecturer \\ School of Accounting \& Business Management \\ FTMS Global Malaysia, \\ Omkar.dastane@gmail.com
}

Received: 21 June 2016 / Revised: 13 July / 2016 / Accepted: 14 July 2016 / Published online: 6 October 2016

\begin{abstract}
Numerous researchers have centred their attention on Customer Perceived Value towards brands but only a few have focussed on CPV towards convenience stores. The main purpose of the research is to measure the CPV dimensions and identify which dimension influences customer satisfaction and as a result leads to customer loyalty and retention for convenience stores in Malaysia. Independent variables such as functional, conditional, social, emotional and economic values were taken into account; the number of 200 customers were sampled, using a blend of explanatory and descriptive research design and a quantitative research method. The reliability was measured ranging from $(\alpha=.560-.966)$ using Cronbach's alpha. The application of descriptive statistics and correlation analysis was intended to explain the relationship between the independent and dependent variables of the research, whereas the inferential statistics and linear regression were used to test the hypotheses; with a significance level $p \leq 0 / 05$ whereby the findings of the research showed that economic value has a high influence on customer satisfaction as well as loyalty and retention. However, based on the findings customers are highly influenced by the economic value they get from a convenience store. Among the realistic contributions are positioning value pricing, formulating a strategy that encourages convenience value, connects to customers' emotions during shopping and also creates a diverse approach that sets a convenience
\end{abstract}

Corresponding author. Head - Centre for Postgraduate Studies cum Senior Lecturer, School of Accounting \& Business Management, FTMS Global Malaysia, Block 3420, Persiaran Semarak Api, Cyber 4, Cyberjaya, Selangor, Malaysia, e-mail: Omkar.dastane@gmail.com 
store apart from another. However, there is a need for future studies to extend the model of this research by adding other perceptions such as demographic features of the consumers.

JEL classification: M310, M390

Keywords: Customer Perceived Value, customer satisfaction, customer loyalty and retention, convenience stores, Malaysian retail

\section{INTRODUCTION}

\subsection{Research Background}

Convenience stores' single best method to increase the service intensity is by recognizing the customer's views (Zemke and Woods, 1998). However, modern retail outlets are rapidly replacing the unorganized traditional retail outlets, which has in turn led to the pervasive recognition of convenience stores (Goldman et al., 1999). These stores offer customers speed of service and are recognized by customers as a channel of trade for their convenience. Nevertheless over the past few years the convenience store industry in Malaysia has grown speedily, with the lifestyle of consumers' moving towards modernity and great contribution from market players such as 7ELEVEN, 99speedmart, KK. Furthermore, drivers like urbanization have increased disposable incomes, shifting demographics as well as lifestyle along with FDI in retail having manoeuvred the sector towards development. Nevertheless, the change as a result of ruthless competition, from emerging players in the market, imitation of new characteristics and an increase in the quantity of new offers, customers' new choices and also sensitivity to pricing, has forced key players in the industry to introduce differentiation and offer customer-oriented formats in order to increase competitive edge (Singh, 2006); for these reasons researchers globally (Reicheld and Sasser, 1990; Ciavolino and Dahlgaard, 2007; Singh, 2006; LaBabera and Mazursk, 1983; Carpenter, 2008) have took notice of the impact of customer satisfaction, retention as well as loyalty.

Nonetheless the perception of 'perceived value' comes out as the major business concern of the 1990s, and has persistently obtained widespread study awareness in the current century (SánchezFernández and Iniesta-Bonillo, 2007). Organizations are progressively more recognizing that the perceived value concept is a significant aspect in strategic management (Mizik and Jacobson, 2003; Spiteri and Dion, 2004). Regardless of this wide curiosity, the concept of 'value' has frequently not been evidently distinct in studies of the topic; certainly, Khalifa (2004) suggested that the perception had turned into one of the largely worn-out and distorted impressions in the management literature in particular. Nevertheless, it is pragmatic that customer perceived value in terms of convenience stores has been entertained in very wide studies in the developed countries, even though the intense volume of research has been carried out predominantly in the UK and the US (Yang, 2009; Christine, 2011; Desmet, 2014). In the developing nations a substantial quantity of research has been carried out; this covers the Asian countries as well as some parts of Africa (Yu Wu, 2014). However, in Malaysia little research on customer perceived value in terms of convenience stores has been done (e.g. Wahid, 2009).

The researchers in the past used a descriptive and exploratory research design (Sweeny, 2011; Pandza, 2007; Sheth, 1991); conversely, it looks as if the majority of the research frequently applied the explanatory research design predominantly for customer perceived value (Davis, 2012; Christine, 2011). So for that reason, to have outstanding research, the researchers propose to apply both descriptive and explanatory research design in order to arrive at a solid as well as comprehensible conclusion; in terms of research methodology, a quantitative research methodology has been expansively applied to customer perceived value by adopting rating 
scale-based questionnaires (Sheth, 1991; Sweeny, 2011). As a result this research proposes to apply a quantitative methodology to carry out the research. In less ambiguous words it gives the impression that the use of qualitative research is less accepted as it is obvious that the quantitative research methodology is widely used (Pandza, 2007). In terms of variables, numerous studies have extensively used definite dependent variables to quantify customer perceived value such as price (Yu et al., 2009); this has been the generally extensively utilized variable in comparison to retention (Carpenter, 2008), brand loyalty (Reicheld and Sasser, 1990), and also customer satisfaction (Singh, 2006). Nevertheless, when appraising CPV of convenience stores, customer satisfaction has been referred to extensively (Singh, 2006; Ciavolino and Dahlgaard, 2007); in regard to the polysemy of the theory of perceived value, there are complications in contrasting the results of diverse empirical research and, accordingly, there is a discrepancy in the depth of perceived value (G.-Gallarza and Gil, 2006). In this sense, there is a compromise regarding the multi-dimensionality of the model of value (Sweeney and Soutar, 2001), accommodating the subsistence of quite a few explanatory features that permit the depth of perceived value. In the scale of retailing, Sweeney and Soutar (2001) created a scale to appraise perceived value that they denominate PERVAL. This scale is among the uncommon endeavours to provide a functioning application of measurement of perceived value at the point of sale. This application symbolizes a pace forward in contrast to theoretical methods (Sales and Gil, 2007). The scale of PERVAL classifies three fundamental aspects of value, that is emotional value (sentimental feelings produced by a product), social value (the efficacy gotten from the product's capability to improve the social perception of consumer) and also functional value, made up of the sub-scopes of price (efficacy gotten from the product as a result of the decline of its supposed short and longer term costs) and value (termed as the performance product). Therefore, since this research is in the range of retailing, the PERVAL scale of measurement will be assumed. However, the increased value of this study is due to the observation that the formation of customer value has to be the reason for the company's subsistence as well as definitely for its success (Slater, 1997, p. 166). As these words specify, the formation of customer value has turned into a crucial strategy in building and maintaining a competitive advantage (Wang et al., 2004).

\subsection{Research Rationale}

The atmosphere of Malaysian retailing industry (convenience store sector) has experienced an uncontrollable as well as noticeable alteration over the decades. Ranges of emerging services from supermarkets as well as convenience stores have been added to the retailing environment (MohdSaid, 1990). In the past, the research commonly tended to scrutinize whether store attributes, service quality, product quality, pricing and environmental location were linked considerably with the customers' satisfaction and loyalty (Seth et al., 1991; Holbrook, 1994, 1999; Sweeny, 2011). Till now, there has not been adequate research that has been performed to scrutinize the core CPV dimensions and how it influences customers' satisfaction, loyalty as well as retention in the retail marketing approach in the Malaysian convenience store perspective (Rahman, 2014). Numerous convenience stores in Malaysia now have been operating in an anticipatory method to recognize the customers' satisfaction with tangibles by means of offering goods or services, except there is a severe lack of confirmation to establish that customers are not completely satisfied (Gomez et al., 2004). The concern now is, as Yuen and Chan (2010) highlighted, that nowadays in the competitive convenience store segment, customers' demands are bound to rise, time after time due to the growth of service quality comparable with multiplicities of products and implausible progress of service industry in which the retailing segment takes up a momentous position. Nevertheless, the perception of 'consumer value' has turned into the essential concern to be concentrated on in all marketing activity (Holbrook, 1994, 1999). It is in some way not easy to 
describe convenience in view of the fact that what a single individual distinguishes as convenient possibly will not be entirely that suitable for another individual.

Yale and Venkatesh (1986) projected a framework for comprehending convenience whereby variables like attitude as well as situational context manipulate an individual's liking and want for a number of the features of convenience. Those features consist of effective time operation, portability, and prevention of conflict in a service. The main factor is that as an individual's circumstance modifies his /her discernment of what is convenient. Brown (1989) defined convenience in a way that focuses on the service as conflicting to the person, breaking convenience up along the five dimensions of a service: time (functional), place (conditional), purchase (economic), exploit (social), and implementation (emotional). Conversely, Clulow and Reimers (2009) carried out a meta-analysis of reviews of convenience in already existing literature, as well as Yale and Venkatesh and Brown, whereby the findings were that convenience in retail develops from decreasing the expenditures of time, space, and endeavour.

In terms of customer perceived value this research proposes to scrutinize concerns associated with CPV dimensions and how it influences customer satisfaction, retention and loyalty. The rising competition for the increase in business, particularly in the retailing industry (convenience store sector), has at all times been very extreme and competitive, thereby forcing companies to seek for innovative approaches to get better and raise their market shares. Thus, understanding the ways to build up customer satisfaction and the category of features that makes customers satisfied has turned into and is still a major worry in retail management nowadays (Pritchard, Havitz and Howard, 1999). The rising rivalry in the Malaysian retailing industry has manipulated and bestowed demands to retailers such as convenience store business owners to look for innovative approaches to distinguish themselves as well as improve their competitive position in customers' mind in order to perk up customer satisfaction, retention as well as loyalty (Osman, 1993).

Nevertheless, the majority of the research illustrates that CPV has a positive influence on brand loyalty, retention, satisfaction as well as repeat purchase (Yang, 2009; Vera, 2013; Yu Wu, 2014); but very little focuses on convenience stores. However, it has remained uncertain what the definite relationship linking CPV dimensions and customer satisfaction, retention and loyalty in the retail segment such as convenience stores is. Consequently, the focus of this research is to scrutinize the relationship between CPV dimensions and customer satisfaction, loyalty and retention as regards convenience stores.

However, most of the research on CPV has been predominantly done in the developed countries, mainly in other areas in the retail industry as well as other industries (Park, 2014; Vera, 2013; Seth, 1991; Lasley, 2011; Marketta, 2012). But not many reviews have been done in the sector of convenience stores predominantly in Malaysia (Wahid, 2009), and these have mainly made use of a descriptive and exploratory research design (Sweeny, 2011; Pandza, 2007; Seth, 1991. However, it appears that the majority of the research universally applied an explanatory research design predominantly to CPV (Davis, 2012; Christine, 2011) by means of certain dependent variables to measure customer perceived value such as price (Yu et al., 2009); retention (Carpenter, 2008), brand loyalty (Reicheld and Sasser, 1990), as well as customer satisfaction (Singh, 2006).

Therefore all these variables will be integrated in this research. On the other hand, in closing the gap, this research was carried out among customers by examining the influence of CPV dimensions on convenience stores in Malaysia.

\subsection{Scope of Research}

The entire research and its findings will be of great significance to convenience stores as the findings will help to increase their customers' satisfaction as well as loyalty and retention; this is for the reason that the research attempts to explain CPV of convenience stores and also its impact 
in general on which of the CPV dimensions has a higher influence on customer satisfaction, loyalty and retention. On the other hand, substantial quantity of research has been done on Customer Perceived Value in various industries and economic sectors and different brands (Chi, 2011; Park, 2014; Vera, 2013; Sheth, 1991; Lasley, 2011) but not so much has been done on convenience stores in Malaysia (Wahid, 2009). The research findings will also be of great benefit to students and researchers for upcoming research whereby they will serve as a reference for others to use them for academic purposes presently and in the future.

\subsection{Research Aim, Research Objectives and Research Questions}

The significance of the research objectives are divided into two. Firstly, the research is aimed at analysing the customer perceived value of existing customers of convenience stores, their products as well as service. Secondly, the research aim is to scrutinize how convenience stores can use this awareness and bring about immense satisfaction, loyalty as well as retention of customers. Since most of the research based on CPV has been on brand only, the research objectives were formulated in order to find out if CPV dimensions influence customer satisfaction as well as loyalty and retention in the case of customers patronizing convenience shops.

\subsubsection{Objectives}

Research objectives are: examining the impact of Customer Perceived Value on customer satisfaction; examining the impact of Customer Perceived Value on customer loyalty; examining the relationship between customer satisfaction and functional value; examining the relationship with customer satisfaction and emotional value, conditional value; examining the relationship with customer satisfaction and social value, economic value; examining the role of customer satisfaction towards customer loyalty and retention.

\subsubsection{Research Questions}

Research questions corresponding to the objectives are: Does the functional value have an impact on customer satisfaction? Does the emotional value have an impact on customer satisfaction? Does the social value have an impact on customer satisfaction? Does the conditional value have an impact on customer satisfaction? Does the economic value have an impact on customer satisfaction? What is the impact of Customer Perceived Value on customer satisfaction and customer loyalty and retention?

\section{LITERATURE REVIEW}

For several years the notions of Customer Perceived Value have been scrutinized within the marketing field. Nevertheless, because of the very extensive review of observable facts, no widespread description has been established. As a result, quite a few authors created diverse definitions of CPV; therefore, in an effort to combine these varied definitions, Woodruff (1997) proposes: "Customer value is a customer's perceived inclination for and appraisal of those product features, feature performances, as well as outcomes occurring from use that make easy (or block) attaining the customer's objectives and idea in use conditions". Khalifa (2004) states that CPV can be assembled into three major groupings: utilitarian models (benefits/costs), price components models, and also means-ends models. On the other hand, Yang and Peterson (2004) described customer perceived value as an undeviating determinant of behavioural intensions as well as consumer loyalty. Ziethmal (1988) elucidates customer perceived value as a general economic viewpoint appraisal of product efficacy by the consumers. In the utilitarian view 
customer perceived value is an assessment by the customer of two proportions - benefits and costs (Kumar and Grisafe, 2004; Roig et al., 2006; Gounaris et al., 2007). In researching the theoretical customer discernment of price, value and quality, furthermore, Zeithaml (1998) explained value as the relative amount of customer perceived product usefulness (benefits received) alienated by the price paid, and highlighted that customer value is based on biased view.

\subsection{Critical Literature Review of Key Models and Theories}

An outline of the literature shows two predominant research methods of the functionalization of value. The initial method regards perceived value as single-dimensional. According to this outlook, perceived value is a single general perception that can be defined by a set of items that examine the consumer's discernment of value (e.g. Agarwal and Teas, 2002; Brady and Robertson, 1999; Chang and Wildt, 1994; Dodds, 1991; Hartline and Jones, 1996; Kerin et al., 1992; Sweeney et al., 1999). In turn, the second method conceives perceived value as a multidimensional construct that comprises a number of consistent features that outline a holistic depiction of a multifaceted trend (e.g. Babin et al., 1994; Huber et al., 2000; Mattsson, 1991; Sweeney and Soutar, 2001). The chosen models and theories are generally chosen for research as, in the case of convenience stores, consumer perception of value is evaluated from a single overall concept or several interrelated dimensions, thereby critically reviewing the suitable models as they give a broad explanation by evaluating customers by different approaches. Some of these research streams are discussed in more detail below.

2.1.1. Axiology or value theory: Hartman $(1967,1973)$ explained an axiological model of the value sphere in regards to extrinsic value, intrinsic value, as well as systemic value. However, 'extrinsic value' replicates the utilitarian use of a meticulous service as a way to a core end, while 'intrinsic value' signifies the emotional approval of the consumption. The phrase 'systemic value' refers to the reasonable aspects of the inbuilt associations among perceptions in customers' systematic dealings - for instance, the affiliation between forfeits as well as profits. Mattsson (1991) adjusted the framework of Hartman $(1967,1973)$ by consigning to three generic value aspects: - emotional (E), which centres on the consumers' feelings; - practical (P), which centres on the substantial and serviceable features of consumption; as well as - logical (L), which centres on the reasonable and conceptual characteristics of the acquisition. In this adjustment, E was conceived as being better than P, which, in turn, was conceived as being better than L. These aspects have established a link in research from a variety of disciplines, together with values, psychology, education, social psychology, and also business management (Danaher and Mattsson, 1994). Several studies have analysed the three-dimensional structure of value in the service encounter. Danaher and Mattsson (1994) assumed the axiological model of Hartman $(1967,1973)$ and established that the three value measurements could be comprehended as background to satisfaction, with every value measurement having both an optimistic and pessimistic proclivity. Finally, Huber et al. (2000) made an addition to these models by including the measurement of 'perceived risk' in the three-dimensional configuration of value. In terms of CPV related to convenience stores this model fails to identify the dimensions of CPV which are functional value (Seth et al., 1991) conditional, emotional and social value (Sheth et al., 1991), which makes the model unfit for the research.

2.1.2. Consumption-value theory: Sheth et al. (1991a; 1991b) declare that the comprehensive consumer preference - to purchase or not to purchase or to decide on one sort of product or service over an alternative and to prefer one brand over an alternative - is based on a variety of structures of value. These types of value can be characterized as functional, social, emotional, epistemic, and conditional.

The usefulness of this framework is in appraising diverse features of a product by means of customer view. However, the majority of the research done on CPV pointed out that the 
customer tends to buy a product on the basis of benefits (Monroe, 1985). However, the theory of consumption-value proved futile in specifying all the fundamental sources of values. On the other hand, Seth et al. (1991) conquered this concern and outlined a range of features of a product, and the way these features derive customer opinion is extremely appropriate to measure the categories of values that a customer receives prior to and subsequent to the purchase of a product. In the case of appraising CPV linked with a convenience store, five variables like functional value, social value, economic value, emotional value, and conditional value appear to be relatively suitable to appraise CPV of a convenience store (Ehsani and Hashim, 2015).

Sheth et al. (1991a) propose three essential schemes that the theory relies on: (i) that market choice is a utility of numerous values; (ii) that these types of value formulate differential assistance in any particular choice circumstances; and (iii) that the types of value are autonomous. The limitation of the theory is that it only reflects the choice by a person and it merely deals with choices which are methodical and voluntary. Ensuing studies of this theory have fixed attention predominantly on the lack of generalizability of its unusual functionality. As a result, Sweeney et al. (1996) created a process for the three aspects of value in the initial multi-dimensional scale - functional, social, as well as emotional; but epistemic value and conditional value measures were exempted as they were not suitable for their study. On the other hand, Williams and Soutar's (2000) study was qualitative and also exploratory, and the findings revealed that all of the value groupings of consumption-value theory (Sheth et al., 1991a) - functional, emotional, social, and epistemic - were obvious for the customers in their research. Exploiting the theory, Sweeney and Soutar (2001) formulated the popular 'PERVAL' model, which was a dimension scale of consumers' insights about the value of resilient goods. Nevertheless, all dimensions of perceived value (functional, social, emotional, and perceived sacrifices) were found to have a momentous consequence for customer satisfaction, even though no considerable confirmation was found to sustain the direct control of whichever dimension of value over customer loyalty and retention. However, this research will also adapt this model of Seth et al. (1991) but will include economic value other than epistemic value that concerns individual status which is not relevant in measuring CPV of a convenience store.

2.1.3. Price and Quality (Monroe, 1985): The price-based unidimensional measure of perceived value by Monroe (1985) focuses on the classification as well as examination of pricequality affiliation. As proposed by Monroe (1985), perceived value is an imperative aspect for customers or the process of purchase decision by consumers. Moreover, customers will purchase a product of an elevated perceived value (Chi et al., 2009). Nevertheless, consumers will definitely measure what is given as well as what is obtained in the individual insight of consumers at the very moment a product is being purchased by a consumer (Monroe, 1985). This framework measures the product price perceived by a consumer as a gauge to appraise perceived quality and sacrifice. It further clarifies that consumers obtain perceived value subsequent to making an assessment of perceived quality against sacrifice. Therefore, according to the framework, the consumer perceived value of a product/service is positive when the perceived quality is greater than the perceived sacrifice (Monroe, 1985). On the other hand, the frameworks' limitation is that it fails to include several constructs that measure perceived value but instead it comprises just price as its construct to measure the customer perceived value, but even as it has just one variable, it appears to be a significant variable in measuring CPV of convenience stores. Other factors of this framework were mulled over for instance in line with Zeithmal (1988) trade-off model which recognized four diverse aspects to measure customer perceived value.

2.1.4. Holbrook's typology of perceived value: Holbrook (1994, p. 22, 1996, p. 138, and 1999, p. 5) described perceived value as an 'interrogative relativistic predilection experience'. Holbrook's (1999) framework is among the main multi-dimensional frameworks that have immensely contributed to the appraisal of customer perceived value. However, about eight variables were used to measure $\mathrm{CPV}$; these are: competence, play, superiority, aesthetics, 
prominence, principles, admiration as well as theology (Holbrook, 1999). A critical characteristic of Holbrook's disagreement is that all eight kinds of perceived value measurement are liable to be 'compresent' - this implies that they are liable to take place collectively to changing degrees in whichever given consumption occurrence. In regards to all the unidimensional and multidimensional methods in the literature of perceived value, however, Holbrook's suggestion, based to some extent on the axiology of value, has been, in the opinion of most, one of the methods that have contributed to the study of the history of perceived value. The theory of this framework refers to the product value which consists of the merchandise and also the services.

In respect to this view, perceived value entails relations involving a matter (the consumer) and an entity (the product); it is virtual, private, and conditional (precise to the perspective); and it exemplifies a penchant judgement. Several theoretical indications on the 'typology of consumer value' have been around (e.g. Bevan and Murphy, 2001; Kim, 2002) and a number of empirical studies have been carried out (Bourdeau et al., 2002; Mathwick et al., 2001, 2002). Predominantly, Mathwick et al. (2001) formulated an experimental value scale that centres on self-oriented constructs of experimental value - that is, a detachment of Holbrook's (1999) consumer-value realm. Similar authors (Mathwick et al., 2002) afterwards applied their scale to scrutinize the impact of consumer shopping activities and the customer retention of information exhibited on consumer discernment of experiential value. Correspondingly, Bourdeau et al. (2002) recognized five value features underlying the application of the internet - communal, utilitarian, hedonic, educational, and procuring. Nevertheless, regardless of its sumptuousness and complication, Holbrook's $(1994,1999)$ method does have limitations. The densities of its configuration cause difficulties to its operationalization in getting some sort of value - like ethical and spiritual values that are relatively ignored in the CPV literature (Brown, 1999; Holbrook, 1999; Wagner, 1999). Additionally, there is a comparatively restricted function for certain features of surrender in this typology, and all except one grouping - competence - refer principally to remunerations alleged by the consumer. For all these as well as other explanations, the small number of present empirical examinations of this typology have enclosed merely decreased sets of certain groupings (Bourdeau et al., 2002; Gallarza and Gil, 2006; Mathwick et al., 2001, 2002).

However, below is a review of relevant theoretical frameworks that are likely to be suitable for the research; nevertheless, due to the limitations of each model analysed above, certain conclusions have been drawn by the researchers and have led to a firm decision to propose a new theoretical framework that is perfectly suitable for the research and measures CPV of convenience stores.

\subsubsection{Review of Relevant Theoretical Models}

Consumption value framework (Sheth et al., 1991)

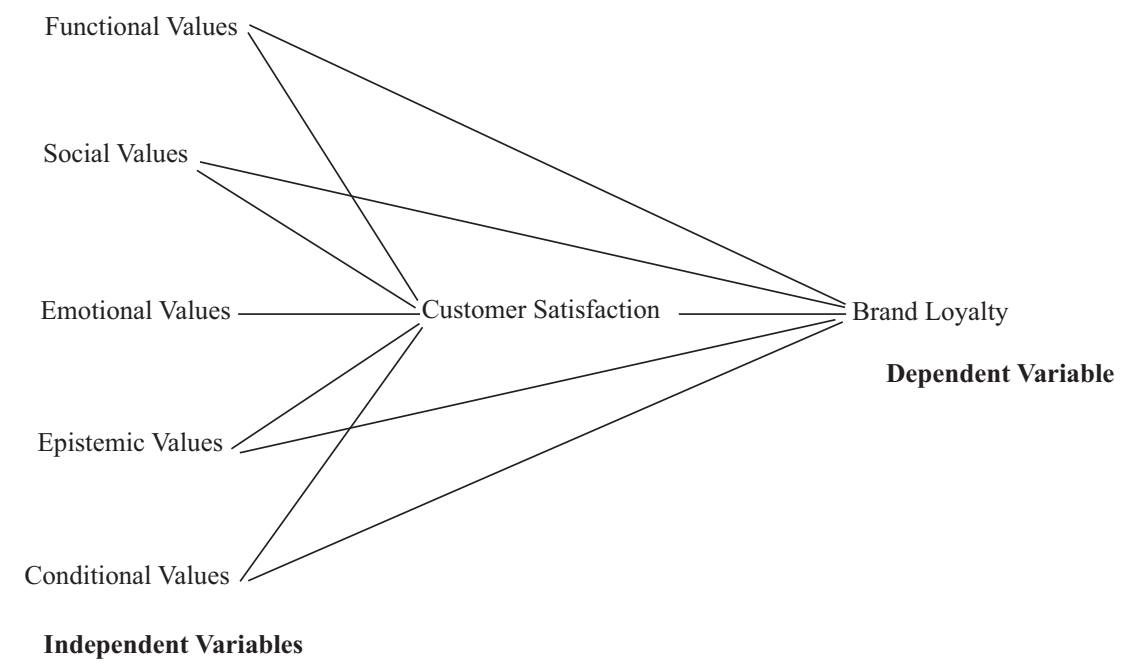


Consumer loyalty to family versus non-family business model (Orth and Green, 2009)

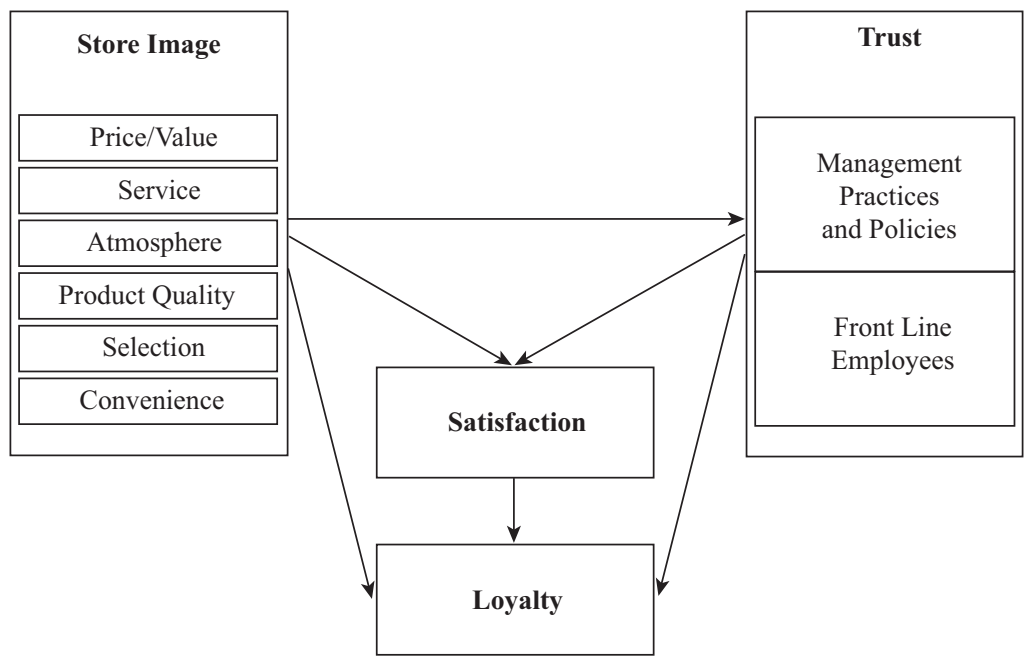

Customer value is deliberated over by utilizing five markers: functional, emotional, social, conditional, and also epistemic value (Sheth et al., 1991). Consequently, customer value in this research is explained as the value of service that is professed by customers subsequent to shopping at a convenience store. Emotional value is associated with the benefits gotten by customers from the atmosphere of a convenience store, whereas social value is a gain associated with the social position of customers of a convenience store. However, the most appropriate model for the research is the consumption-value theory (Sheth et al., 1991), since the research is on convenience stores. Sheth's model has limitations as economic value is not considered in this model but is significant for convenience stores as convenience stores are generally expensive, making epistemic value less significant as customers do not visit convenience stores for status or curiosity purposes but rather for value for money and satisfaction of present needs. However, it is necessary to propose a model that modifies Sheth's one slightly in order to provide a suitable model for the research.

\subsection{Proposed Conceptual Framework}

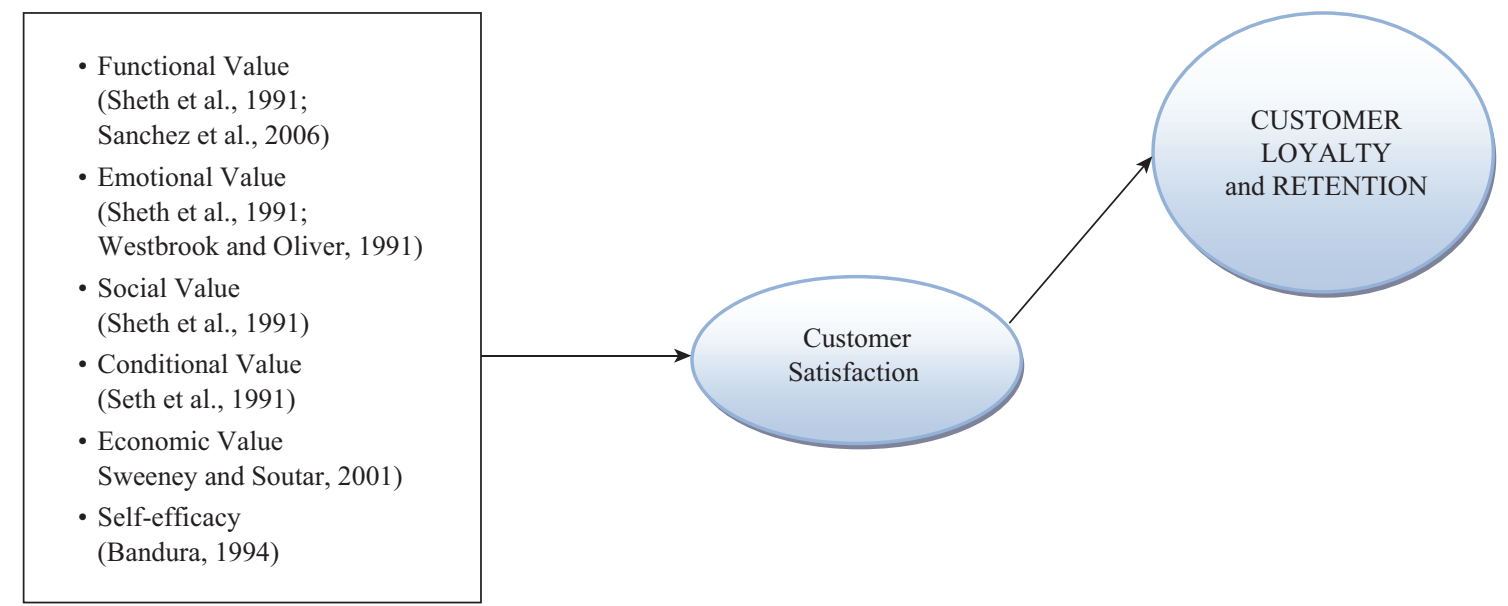

From the above proposed framework, customer value is a significant factor that is considered by customers in terms of purchase intentions. Improved customer value, as in contrast to what other companies in the industry deliver, will make a customer feel satisfied and as a result will bring about loyalty of consumers. It is established by Kotler (2013) that customers will buy from a firm which they believe to give the maximum value for the customer. In regards to the theory of customer satisfaction, it is the intensity of a customer's awareness subsequent to evaluating 
the tangible performance of a product that a customer recognizes as compared to what he/she anticipated. McQuity et al. (2000) declare that if consumers understand that even the smallest expectation is met, it will boost customer satisfaction. Additionally, Kotler and Armstrong (2004) claimed that consumers constantly necessitate businesses' offering merchandise or service that is capable of satisfying the requirements of customers. Regarding the affiliation between customer satisfaction and customer loyalty, as Kotler (2013) said, an extremely satisfied customer usually remains loyal for a long period of time, purchases extra as the firm launches new products and improves already existing products, converses positively about the firm and its products, spends less on competing brands, and is not as much susceptible to price, gives ideas of products/service to the firm, as well as costs less than new customers.

2.2.1. Functional Value: is an individuals' realistic and economic evaluation of the superiority of the product and service (Woodruff, 1997; Sanchez et al., 2006). A variety of functional value characteristics materializes from the widespread review; this includes responsiveness (Parasuraman, Zeithaml and Berry, 1988), suppleness (Lapierre, 2000), dependability (Parasuraman et al., 1988), sympathy (Parasuraman et al., 1988), convenience (Schmenner, 1986) and price (Anderson and Narus, 1998). Sanchez et al. (2006) and Sweeney and Soutar (2001) also projected that functional value is connected to responsiveness, dependability, suppleness, sympathy as well as price. Thus, this aspect replicates the derived compensations from the quality of the product, product performance and derived product's value for money. Consequently, functional value is however connected to the SERVQUAL model's second and third dimensions; reliability is the second dimension of the model and also contains two sub-dimensions which are assurance (Dabholkar et al., 1996) and accessibility of goods/services (Westbrook, 1981). The guarantee sub-dimension evaluates the consumer's perception that the store will keep its promise, while the accessibility dimension concerns the perception of the consumer whether the consumer can rely on the accessibility of goods/services. The third dimension is individual communication. It has two sub-measurements: first - responsiveness and second - politeness. These sub-measurements are in close relation and capture how promptly and how well the customer is taken care of by the staffs of the business. Nevertheless, functional value above all displays how practical a product is, and whether it fulfils the functions expected of it (Smith and Colgate, 2007). These measurements have manipulated on CPV for the consumer, which is an imperative aspect that impacts the satisfaction of the customer (Gill et al., 2007).

2.2.2. Emotional Value: Emotional value includes the belief that a customer derives from the consumption experience of a product and also a service (Sheth et al., 1991). Yu and Dean (2001) disputed that the emotional factor is momentous to determine customer satisfaction. A number of academicians revealed that there is a well-built effect on satisfaction from pessimistic rather than optimistic emotions. Therefore, emotions are dominant in outlining the outcomes and influence of several organizational experiences like: customer satisfaction (Buciuniene et al., 2009; Liljander and Stranvik, 1997; Freemantle, 1998; Youngdahl and Kellogg, 1997). According to Westbrook and Oliver (1991), the perception of consumption emotion is a reply throughout the experiences of consumption. Momentarily they clarified that consumption emotions are characterized by a variety of experiences and terms, such as apprehension, happiness and resentment.

2.2.3. Social Value: Social value has an undeviating relation with social position. These measurements of social capital and the well-being of social citizens make extensive impression on the customers' mind. This can be the capability of participating in decision making that impacts them. The social factor signifies benefits which may come from referrals of others like friends and family (Tabassum et al., 2013). Therefore, social value is the value gotten from the product's or service's capability of improving social self-concept (Sweeney and Soutar, 2001); this can be described as the perceived efficacy obtained as a result of having relations between single or multiple social groups as well as consumer choice (Panda, 2007). However, social values are measured as the majority of imperative multi-dimensional variables which manipulate purchasing 
intentions of consumers, which has an undeviating effect on customer satisfaction as well as plays a vital role in encouraging individuals to incessantly utilize convenience stores and stay loyal to the company.

2.2.4. Conditional Value: is defined by Ehsani, $Z$ and Hashim, N. (2015) in assessing the CPV of a customer doing shopping in convenience stores. Nevertheless, conditional value is the perceived benefit derived in a specific situation. According to Sheth et al. (1991), this kind of customer value replicates the condition in which numerous or few market assortments are reliant on the particular circumstances a consumers encounters for a product or services. The point of view given above is an apparent description that restrictive value is suitable to evaluate customer satisfaction which ultimately leads to loyalty resulting from the circumstances at the moment of necessity by customers of a convenience store.

2.2.5. Economic Value (Price): However, the current research challenges the fact that perceived value is a multifaceted dimension that comprises additional simple reasonable appraisal of 'value'. In addition, 'price' is, in itself; an unclear as well as indefinable notion (Dodds et al., 1991; Woodruff and Gardial, 1996). Even though 'price' is frequently unspoken as the financial worth of a product, a jam-packed admiration of the perception also adds deliberation of time, endeavour and exploration included in the general cost or sacrifice formulated by the customer in the experience of consumption. It is consequently noticeable that perceived value is a wider and better construct than a simple trade-off between 'value' and 'price' (Monroe, 1990; Zeithaml, 1988).

Conclusively, Schiffman and Kanuk (2004) state that the general purpose of offering worth to customers incessantly and more efficiently than competitors is to obtain as well as to maintain extremely satisfied customers. However, the concept of satisfaction has been extensively reviewed as an analysis of customer loyalty (Cronin et al., 2000; Fornell et al., 1996; Yang and Peterson, 2004). This general satisfaction has a very firm optimistic influence on customer loyalty intents over a wide range of categories of merchandise and service (Gustafsson, 2005). Furthermore it is an imperative feature for a long-term affiliation between an organization and customer (Anderson and Srinivasan, 2003). Based on the above in-depth review of suitable models and theories, the purpose of the research was to see if CPV dimensions influence customer satisfaction and customer loyalty and retention of convenience store customers, rather than just examining the influence of a brand as in most research; therefore, the research attempted to fill the gap.

\section{DATA AND METHODS}

Research Philosophy: The projected research notion for this research was the positivist philosophy. The researchers intended to evaluate the research data by employing validity and reliability test to the data analysis. Research Design: As a result of the research type that leans towards a practical technique, the research intended to employ the combination of a descriptive and explanatory research design. Research Methods: The research took on a quantitative research methodology as it planned to assemble data from a huge number of customers so as to quantify how CPV is influenced by customer satisfaction and customer loyalty. Consequently, in connection to the objectives of this research, the consideration of primary research was perceived to be more pertinent to the study aim so as to offer lustre and comprehension of customer perceived value in the retail sector, precisely convenience stores.

Data Collection, Sampling Procedures and Target Population: This research applied a nonprobability sampling technique as well as quota sampling. Concerning this research, quota sampling helped to segregate the respondents by gender, and also due to the reality that quota sampling was fundamental as it necessitated the chosen populace to be segregated into subgroups 
in order to ensure significance of the obtainable data and also to estimate a ratio for each chosen group as well as it was connected to the little improvements figured out by Saunders et al. (2010). Data collection was carried out by handing out questionnaires to respondents who gave their consent to the researchers in a signed consent form made available on the first page of each questionnaire. This method of sampling is ideal for the research as it is cost effective and time saving. Furthermore a sample of 200 respondent was selected. The researchers intended to add 25 to the sample size to have a large sample in order to arrive at the sample size of exactly 200 in case of mistakes by certain respondents. Questionnaire: The researchers designed a selfadministered questionnaire. The researchers premeditated the questionnaire with 6 questions in 3 sections and 5 questions in 4 sections on a five-point Likert scale (Burns and Bush, 2000) and the questionnaire was reviewed using five foremost customer perceived value dimensions (emotional value, social value, functional value, economic value and conditional value). These are measurement instruments employed in previous studies by Sanchez et al. (2006) and Roig et al. (2006) whereby the questions were designed in a straightforward, less vague manner, with the observance of content, reliability measures as well as construct dependability. Each variable was measured by sub-variables which translate the main variable and questions were derived from the sub-variables. For instance, social value describes the convenience gotten from product or service capability of enhancing self-concept; in order to create the questions a twist was made by the researchers for the measurement to suit convenience stores. As it does not focus on product, 3 sub-variables were used: decision-making, values and attitude (Panda, 2007; Sweeny and Soutar, 2001).

Analysis Tools: A survey Likert-scale questionnaire was the applied data collection tool for this research, as it was the most common tool used by past researchers (Bjorn, 2013; Sandra, 2012); however, it was applied as it is a less expensive approach for the researcher and it permits the respondents to make their responses in an adequate manner. Furthermore, in order to establish a relationship between the CPV dimensions and customer satisfaction as well as customer loyalty and retention, a correlation as well as a multiple regression analysis tools were applied to measure the relationship. This analysis tools helped the researchers to know the extent to which CPV dimensions influence customer satisfaction and customer loyalty and retention. The first step in the analysis was a check of reliability of all collected data and then the final stage of the analysis was the relationship testing using regression analysis. The hypotheses formulated for this research were tested at the level of 5\% significance. The regression formula is: $\alpha=a+b \beta+u i$, where; $\alpha=$ dependent variable, $\beta=$ independent variable, $a=$ intercept, $b=$ slope, $u i=$ error term. Ethical issues: Ethical issues were minimized by the researchers in possible ways such as the consent form, the use of straightforward questions in the researchers' questionnaire and also minimizing the amount of plagiarism in the secondary data collection. But the issue that the researchers could not avoid were untrue answers by respondents in the primary data collection. Limitations of Research: This research is not without its limitations in terms of biasness of respondents which might have an effect on the results. Another limitation is that the research does not focus on a certain brand or product or consumer-but its focus is on the convenience store in general. Nevertheless, the research findings are likely to oppose the findings of previous research. Furthermore, the subjects did not have enough time to answer the questions; therefore, a longer period of time was utilized to collect data as not all the respondents were willing. Another limitation is the language barrier for some subjects and also the sample size as it did not allow a general conclusion to be drawn on $\mathrm{CPV}$ of convenience store customers. 


\section{RESULTS AND DISCUSSION}

\subsection{Analysis of Demographic}

For the demographic section, the respondents are divided into 7 different groups which are gender, age, the level of education, relationship status, total annual household income, sociocultural background as well as the number of times they visited the establishment (convenience store). However, for the significance of the research, gender, age, total household income and the number of visits to the establishment were analyzed. In terms of gender, $61 \%$ of the respondents are males and $39 \%$ are females; this lesser share of females can only be attributed to the fact that the researchers are male and have freer interactions with males. In terms of age, 33\% of the respondents are in the age range of $18-22$ years while $43.5 \%$ are $23-30,16 \%$ are $31-40,5.0 \%$ are 41-50 and only $2.5 \%$ are 51 and above. The variations in the age percentages show that the age group of 23-40 indicates that they visit convenient stores more, which can be attributed to office hours, school hours and household responsibilities. In terms of the level of household income and the number of visits to convenience stores, among low household income earners: 58 respondents visit convenience stores daily; 36 respondents weekly and 3 respondents monthly. For medium household income earners: 22 respondents visit convenience stores daily, 52 respondents weekly and 4 respondents monthly, and finally for high household income earners: 9 respondents daily, 9 respondents weekly and only 4 respondents monthly. This explains that household income would not influence the number of times individuals visit a convenience shop.

Table 1

Socio-demographic analysis

\begin{tabular}{|c|c|c|c|c|}
\hline Variable & Categories & Frequency & Percent & Cumulative Percent \\
\hline \multirow{5}{*}{ Age Group } & $18-22$ & 66 & 33.0 & 33.0 \\
\hline & $23-30$ & 87 & 43.5 & 76.5 \\
\hline & $31-40$ & 32 & 16.0 & 92.5 \\
\hline & $41-50$ & 10 & 5.0 & 97.5 \\
\hline & 51 and above & 5 & 2.5 & 100 \\
\hline \multirow{2}{*}{ Gender } & Female & 78 & 39.0 & 100 \\
\hline & Male & 122 & 61.0 & 61.0 \\
\hline \multirow{3}{*}{$\begin{array}{l}\text { Annual Household } \\
\text { Income }\end{array}$} & Low & 100 & 50.0 & 100.0 \\
\hline & Medium & 79 & 39.5 & 50.0 \\
\hline & High & 21 & 10.5 & 10.5 \\
\hline \multirow{3}{*}{ Number of Visit } & Daily & 92 & 46.0 & 46.0 \\
\hline & Weekly & 97 & 48.5 & 94.5 \\
\hline & Monthly & 11 & 5.5 & 100.0 \\
\hline
\end{tabular}

\subsection{Measure Validation}

A pre-test was carried out before conducting the analysis, with a group consisting of twenty customers; so the results allowed us to believe the definitive questionnaire. The researchers used Cronbach's alpha to measure the reliability of the questionnaire. It is significant as it is the reliability coefficient that indicates how positively all items are correlated (Sekaran, 2000). Therefore, in order for the scale to be consistent it must have a satisfactory value of 0.6 although Cronbach's value is within the range of 0 to 1 (Cronbach, 1951; Malhotra, 2002); this implies that 
the closer to 1, the higher the internal consistency and the research is bias free as well (Bollen, 1989). The reliability evaluation of every dimension is from 0.500 to 0.966 . Not all measures reveal a satisfactory psychometric property in terms of the estimates of reliability. As a result it can be stated that the questionnaire of this particular study is reliable as the overall reliability for all dimensions is 0.925 (Table 2).

Table 2

Reliability analysis

\begin{tabular}{|c|c|c|c|}
\hline Main Variable & Sub-variables & Number of Items & Cronbach's Alpha $(\alpha)$ \\
\hline \multirow{6}{*}{ Customer Perceived Value } & Functional Value & 6 & 0.966 \\
\hline & Emotional Value & 6 & 0.952 \\
\hline & Social Value & 5 & 0.901 \\
\hline & Conditional Value & 5 & 0.913 \\
\hline & Economic Value & 5 & 0.500 \\
\hline & Overall CPV & 28 & 0.925 \\
\hline Customer Satisfaction & Satisfaction & 5 & 0.822 \\
\hline Customer Loyalty and Retention & Loyalty & 5 & 0.560 \\
\hline
\end{tabular}

\subsection{Sample Competence}

In the aftermath of scrutinizing the reliability and also the validity of scale, the researchers decided to test appropriateness of the collected data for the purpose of running a factor analysis. However, the sample size is very significant in the measurement of factor analysis appropriateness; this statement is supported by MacCallum et al. (1999) They conducted a study showing that the lowest amount of sample size depends on other characteristics of the study design. MacCallum et al. (1999) explained further that as communalities turn out to be lower, the significance of the size of the sample increases. Therefore, according to them if each and every communality is higher than 0.5 , then a comparatively small samples size such as 100 may be entirely sufficient. Since the current research sample size is 200 , it is therefore entirely adequate for factor solution in view of the fact that all communalities are from 0.5 -above with the exception of FV6, EV5, SV5 and ECV2. The outcome recommended scrutinizing the sample competence by means of KaiserMayer-Olkin (KMO) method.

Table 3

KMO and Bartlett's Test

Kaiser-Meyer-Olkin Measure of Sampling Adequacy.

Bartlett's Test of Sphericity

$\begin{array}{ll}\text { Df } & 378 \\ \text { Sig. } & .000\end{array}$

The variation of KMO statistics is between 0 and 1. According to Kasier (1974), values that are greater than 0.5 are satisfactory. Therefore, values between 0.5 and 0.7 are second-rate, values between 0.7 and 0.8 are superior, and values between 0.8 and 0.9 are outstanding (Field, 2000). The present study factor analysis is outstanding and significant as its values are between 0.8 and 0.9 (Kaiser-Meyer-Olkin $=0.888$, Bartlett's Test of Sphericity was significant at $p=0.000$ level). As a result of the above analysis it was recommended that the researchers should retain all variables planned at the beginning in the scale construct. 


\subsection{Descriptive Analysis}

The below descriptive statistic table illustrates all the constructs mean values as well as the standard deviation that depicts the psychological personality of the respondents. High mean values were obtained for all of the constructs except social value which is slightly lower than other constructs.

Referring to the above descriptive statistic table, emotional value has an obvious higher mean of 4.16. Studies have supported the claim that emotions are significant in determining the outcomes as well as influence of several organizational experiences (Buciuniene et al., 2009; Liljander and Stranvik, 1997; Freemantle, 1998; Youngdahl and Kellogg, 1997). Additionally conditional value has shown a high mean of 3.790. This high mean correlates with the study and is considered appropriate by Ehsani and Hashim (2015), who ascertain that conditional value is considered suitable in determining the Customer Perceived Value of a customer connected to convenience stores. However, economic value and functional value mean values 3.686 and 3.650 of both constructs are said to be significant in measuring CPV (Sanchez et al., 2006; Woodruff and Gardial, 1996), while social value has a slightly lower mean than other constructs (3.592), making it the construct with the lowest mean; this mean result of the research contradicts Sweeney and Soutar (2001), Tabassum et al. (2013) and Panda (2007), who explained that social value is one of the most significant constructs in measuring a customers' CPV.

Table 4

Descriptive Mean Analysis

\begin{tabular}{|c|c|c|c|}
\hline & Mean & Std. Deviation & $\mathbf{N}$ \\
\hline Functional Value & 3.686 & .6966 & 200 \\
\hline Emotional Value & 4.16 & .786 & 200 \\
\hline Social Value & 3.592 & .7195 & 200 \\
\hline Conditional Value & 3.790 & .5677 & 200 \\
\hline Economic value & 3.650 & .6526 & 200 \\
\hline Customer Satisfaction & 3.606 & .6937 & 200 \\
\hline Customer Loyalty and Retention & 3.657 & .5799 & 200 \\
\hline
\end{tabular}

\subsection{Correlation}

The correlation table below gives a detailed explanation how highly correlated each construct is; correlation coefficient is in the range of 0.231 and 0.750 . Therefore, this implies that all CPV drivers have a positive relationship with customer satisfaction and customer loyalty and retention; the same goes for customer satisfaction having a positive relation with customer loyalty and retention. On the other hand, economic value is highly correlated with customer satisfaction (0.841) and customer loyalty and retention (0.706). This outcome illustrates a very strong relationship to both variables; this affirms that economic value in itself is an indefinite and intangible construct (Dodds et al., 1991; Woodruff and Gardial, 1996). The emotional value depicts the weakest correlation with customer satisfaction and customer loyalty and retention of 0.231 and 0.192 respectively; this result contradicts the claim that emotions are significant in determining the outcomes as well as influence of several organizational experiences such as customer satisfaction (Buciuniene et al., 2009; Liljander and Stranvik, 1997; Freemantle, 1998; Youngdahl and Kellogg, 1997). Correlation coefficients of functional value at 0.530 and 0.537; social value 0.750 and 0.659 as well as conditional value 0.494 and 0.482 show a strong relationship with customer satisfaction as well as customer loyalty and retention. 
Table 5

Correlation Between CPV and Customer Loyalty and Retention

\begin{tabular}{l|c|c|c|c|}
\hline \multicolumn{1}{|c}{ Factor } & $\begin{array}{c}\text { Correlation } \\
\text { Satisfaction }\end{array}$ & $\mathbf{P}<\mathbf{0 . 0 5}$ & $\begin{array}{c}\text { Correlation with } \\
\text { Customer Loyalty and } \\
\text { Retention }\end{array}$ & P $<\mathbf{0 . 0 5}$ \\
\hline Functional Value & $0.530 * *$ & Significant & $0.537 * *$ & Significant \\
\hline Emotional Value & $0.231 * *$ & Significant & $0.192 * *$ & Significant \\
\hline Social Value & $0.750 * *$ & Significant & $0.659 * *$ & Significant \\
\hline Conditional Value & $0.494 * *$ & Significant & $0.482 * *$ & Significant \\
\hline Economic Value & $0.841 * *$ & Significant & $0.713 * *$ & Significant \\
\hline Customer Satisfaction & 1 & & $0.706 * *$ & Significant \\
\hline
\end{tabular}

**. Correlation is significant at the 0.01 level (2-tailed).

\subsection{Multiple Regression Analysis}

The researchers performed a multiple regression analysis in order to examine how well the two dependent variables (customer satisfaction and customer loyalty and retention) are explicated by the independent variables - functional value, emotional value, social value, conditional value and economic value. The outcome of the standard regression is shown in Tables 6 and 7.

Table 6

Model Summary in Calculating Customer Satisfaction

\begin{tabular}{c|c|c|c|c|}
\hline Model & R & R Square & Adjusted R Square & Std. Error of the Estimate \\
\hline 1 & $0.857^{\mathrm{a}}$ & 0.735 & 0.728 & 0.3615 \\
\hline
\end{tabular}

The above result depicted in Table 6 proves that $\mathrm{R}$ is $0.857^{\mathrm{a}}$; $\mathrm{R}$ square is 0.735 and 0.728 for adjusted $\mathrm{R}$ square. This signifies that $0.728=72 \%$ of the inconsistency in customer satisfaction can be clarified by the adjustment in the independent variables of CPV. However, the outcome of the adjusted R square makes this model a 'good fit' as this multiple regression model sufficiently explained more than $60 \%$ of the variance in customer satisfaction (dependent variable). This finding is supported by Sweeney and Soutar (2001), Wang et al. (2004) and William and Soutar (2000), who explained that all dimensions of perceived value (functional, social, emotional, conditional and economic) were found to have a momentous consequence for customer satisfaction.

\section{Table 7}

Customer Satisfaction Regression Model

\begin{tabular}{|c|c|c|c|c|c|c|}
\hline & \multirow{2}{*}{ Model } & \multicolumn{2}{|c|}{ Unstandardized Coefficients } & \multirow{2}{*}{$\begin{array}{l}\text { Standardized Coefficients } \\
\text { Beta }\end{array}$} & \multirow{2}{*}{$\mathrm{t}$} & \multirow{2}{*}{ Sig. } \\
\hline & & B & Std. Error & & & \\
\hline \multirow{6}{*}{1} & (Constant) & .158 & .205 & & .770 & .442 \\
\hline & Functional Value & -.043 & .050 & -.043 & -.866 & .338 \\
\hline & Emotional Value & .008 & .035 & .009 & .228 & .820 \\
\hline & Social Value & .235 & .059 & .243 & 3.992 & .000 \\
\hline & Conditional Value & .047 & .056 & .038 & .829 & .408 \\
\hline & Economic Value & .701 & .067 & .660 & 10.531 & .000 \\
\hline
\end{tabular}

Dependent variable: Customer Satisfaction 
The above Table 7 result shows that only two drivers of CPV are significant out of the five drivers manipulating customer satisfactions; these are Social Value $(\mathrm{SV}=0.000 \mathrm{P}<0.05)$ and Economic Value $(\mathrm{EVC}=0.000 \mathrm{P}<0.05)$. Therefore, the remaining three drivers are insignificant and as a result do not influence customer satisfaction. The other three variables are not significant in influencing customer satisfaction.

\section{Customer Satisfaction $=0.243(\mathrm{SV})+0.660(\mathrm{ECV})+0.158$}

The above written model proposes that the modifications in Economic Value (ECV) can create a major influence on the level of customer satisfaction as Economic Value Beta coefficient $(0.660)$ is the highest and also significant.

Table 8

Model Summary in Calculating Customer Loyalty and Retention

\begin{tabular}{c|c|c|c|c|}
\hline Model & R & R Square & Adjusted R Square & Std. Error of the Estimate \\
\hline 2 & $0.743^{\mathrm{a}}$ & 0.552 & 0.541 & 0.3930 \\
\hline
\end{tabular}

The above result depicted in Table 8 proves that $\mathrm{R}$ is $0.743^{\mathrm{a}}$; $\mathrm{R}$ square is 0.552 and 0.541 for adjusted $\mathrm{R}$ square. This signifies that $0.541=54 \%$ of the inconsistency in customer loyalty and retention can be clarified by the adjustment in the independent variables of CPV. However, the outcome of the adjusted R square makes this model a 'poor fit' as this multiple regression model sufficiently explained less than $60 \%$ of the variance in customer satisfaction (dependent variable), whereas generally it has to be more than $60 \%$ of the variance. This finding is not supported by Sweeney and Soutar (2001), Wang et al. (2004) and William and Soutar (2000), who explained that all dimensions of perceived value (functional, social, emotional, conditional and economic) were found to have a momentous consequence for customer satisfaction but no significant verification was found to support the direct manipulation of any of the CPV dimensions on customer loyalty and retention.

Table 9

Customer Loyalty and Retention Regression Model

\begin{tabular}{|c|c|c|c|c|c|c|}
\hline & \multirow{2}{*}{ Model } & \multicolumn{2}{|c|}{ Unstandardized Coefficients } & \multirow{2}{*}{$\begin{array}{c}\text { Standardized Coefficients } \\
\text { Beta }\end{array}$} & \multirow{2}{*}{$\mathbf{T}$} & \multirow{2}{*}{ Sig. } \\
\hline & & B & Std. Error & & & \\
\hline \multirow{6}{*}{1} & (Constant) & 1.018 & .223 & & 4.566 & .000 \\
\hline & Functional Value & 0.88 & .054 & .106 & 1.625 & .106 \\
\hline & Emotional Value & -.025 & .038 & -.034 & -.665 & .507 \\
\hline & Social Value & .174 & .038 & .216 & 2.728 & .007 \\
\hline & Conditional Value & .098 & .064 & .096 & 1.601 & .111 \\
\hline & Economic Value & .390 & .072 & .439 & 5.395 & .000 \\
\hline
\end{tabular}

Dependent variable: Customer Loyalty and Retention

The above table 9 result shows that only two drivers of CPV are significant out of the five drivers manipulating customer loyalty; these are Social Value $(\mathrm{SV}=0.007 \mathrm{P}<0.05)$ and Economic Value $(E V C=0.000 \mathrm{P}<0.05)$. Therefore, the remaining three drivers are insignificant and as a result do not influence customer loyalty and retention. The other three variables are not significant in influencing customer loyalty and retention. On the other hand, the constant is significant at $(0.000 \mathrm{P}<0.05)$. Previous research has found that social values are considered to be 
the most important multi-dimensional variables which influence consumers and their purchasing intentions (Sweeney and Soutar, 2001).

\section{Customer Loyalty and Retention $=0.216(\mathrm{SV})+0.439(\mathrm{ECV})+\mathbf{0 . 1 5 8}$}

The above written model proposes that the modifications in Economic Value (ECV) can create a major influence on the level of customer loyalty and retention as Economic Value Beta coefficient (0.439) is the highest and also significant.

Table 10

Model Summary in Calculating Customer Loyalty and Retention

\begin{tabular}{|c|c|c|c|c|}
\hline Model & R & R Square & Adjusted R Square & Std. Error of the Estimate \\
\hline 2 & $0.706 a$ & 0.498 & 0.496 & .4118 \\
\hline
\end{tabular}

The above result depicted in Table 10 proves that $\mathrm{R}$ is $0.706^{\mathrm{a}}$; $\mathrm{R}$ square is 0.498 and 0.496 for adjusted $\mathrm{R}$ square. This signifies that $0.496=49 \%$ of the inconsistency in customer loyalty and retention can be clarified by the adjustment in the independent variable of customer satisfaction. However, the outcome of the adjusted R square makes this model a 'poor fit' as this multiple regression model sufficiently explained less than $60 \%$ of the variance in customer loyalty and retention (dependent variable), whereas generally it has to be more than $60 \%$ of the variance.

Table 11

Customer Loyalty and Retention Regression Model

\begin{tabular}{|c|c|c|c|c|c|c|}
\hline & \multirow{2}{*}{ Model } & \multicolumn{2}{|c|}{ Unstandardized Coefficients } & \multirow{2}{*}{$\begin{array}{c}\text { Standardized Coefficients } \\
\text { Beta }\end{array}$} & \multirow{2}{*}{$\mathbf{T}$} & \multirow{2}{*}{ Sig. } \\
\hline & & B & Std. Error & & & \\
\hline \multirow{2}{*}{1} & (Constant) & 1.530 & .155 & & 9.818 & .000 \\
\hline & Customer Satisfaction & .590 & .042 & .706 & 14.018 & .000 \\
\hline
\end{tabular}

The above analysis in Table 11 shows that customer satisfaction is a significant and positive driver of customer loyalty and retention (adjusted $\mathrm{R}$ square $=0.496, \mathrm{p}=0.000$ ); thereby the findings support the findings of Cronin et al. (2000), Fornell et al. (1996), Yang and Peterson (2004) that customer satisfaction is a significant interpreter of customer loyalty and retention. Generally customer satisfaction has a positive effect on customer loyalty (Gustafsson, 2005).

\section{Customer Loyalty and Retention $=0.706($ Customer Satisfaction $)+1.530$}

The above written model proposes that when customer satisfaction is enhanced even as other things stay constant, there will be an improvement in customer loyalty and retention.

\section{CONCLUSION AND RECOMMENDATIONS}

\subsection{Conclusion}

The objectives of this research were to scrutinize whether the dimensions of CPV have a relationship that positively influences customer satisfaction as well as customer loyalty and retention. It was based on the psychological CPV dimension drivers of customers who visit 7Eleven stores. Therefore, the findings of the research conclude that despite slight variations, functional value, emotional value, social value, conditional value and economic value considerably 
influence customer satisfaction as well as customer loyalty and retention (Sweeney and Soutar, 2001; Wang et al, 2004; William and Soutar, 2000).

\subsubsection{Examining the impact of Customer Perceived Value on customer satisfaction}

The finding of the research proves that not all drivers of Customer Perceived Value have a positive relationship with customer satisfaction; Table 7 result shows that only social value and economic value have significant influence on customer satisfaction. This finding is supported by Sweeney and Soutar (2001), Wang et al. (2004) and William and Soutar (2000), who explained that all dimensions of perceived value (functional, social, emotional, conditional and economic) were found to have a momentous consequence for customer satisfaction. Therefore, based on the research findings it confirms Sweeny and Soutar (2001, 2000), as there is a possibility for any of the perceived value dimensions to momentously influence customer satisfaction. However, in terms of social value, the authenticity of the findings can be linked to the development of the research questionnaire whereby the questions were created with sub-variables, which is supported by the Theory of Reasoned Action (Ajzen and Fishbein, 1980) that confirms that consumer attitude manipulates consumer purchase actions (decision making), whereby action is determined by goals, which are also influenced by attitudes and individual values.

\subsubsection{Examining the impact of Customer Perceived Value on customer loyalty and retention}

The finding of this study also validated the formation of customers' perceived values and loyalty. It was found that customers' perceived values of a product or a service will influence their satisfaction. Customers who are satisfied with a service will continuously use the service and become loyal customers. But for a convenience store, based on the findings in Tables 5 and 9, two values are highly significant in influencing customer loyalty and retention. However, the customer loyalty variable is measured by five dimensions of CPV, but two variables are more significant. This can be attributed to the ease a convenience store provides, which leads to word of mouth or telling others optimistic things, which is attributed to social value, and the time and effort a convenience store saves can be attributed to economic value. These findings are in line with Jim Novo (2011), who explained customer loyalty as a propensity of a customer to choose a certain brand of business or product to fulfil their needs. In this case customers choose convenience stores to fulfil their needs; therefore, this can be said to be a situational loyalty for convenience store customers.

\subsubsection{Examining the relationship between customer satisfaction and functional value}

Functional value has been widely used in studies of CPV and has been found to be significant in influencing customer satisfaction (Sweeney and Soutar, 2001; Gill et al., 2007). However, the findings of the research (Tables 5 and 7) proved that functional value is insignificant in influencing customer satisfaction when related to a convenience store. These findings can be explained as the fact that most research has been product or brand based, and thus functional value mainly reveals how functional a product/brand is (Smith and Colgate, 2007). Nevertheless, as regards convenience store customers, the research findings prove that they do not perceive function value like this; therefore, satisfaction is not derived from the responsiveness, flexibility and reliability of a product but rather customers derive satisfaction from the immediate meeting of a need that a convenience store caters for.

\subsubsection{Examining the relationship with customer satisfaction and emotional value, conditional value}

For emotional value, the findings depicted in Table 4 show emotional value to have a high mean value, but when correlated with customer satisfaction, the relationship is weak (Table 7); thereby the research findings contradict the findings of Yu and Dean (2001), who disputed that 
emotional value is vital to determine customer satisfaction. However, some scholars revealed that there is a strong effect on satisfaction from emotions that are negative rather than emotions which are positive. Therefore, consumers who by any means develop emotional responses that are positive for a product or service will in turn obtain a stronger relationship as well as obligation to an organization (Lilijander and Strandevik, 1995); that perception of consumption emotion is a reaction lasting throughout the period of consumption experience (Westbrook and Oliver, 1991). The above discussion reveals that in terms of convenience store experience the emotional factor is not so significant.

\subsubsection{Examining the relationship with customer satisfaction and social value and economic value}

The research finding in Tables 5 and 7 reveals that social and economic value has a high positive influence on customer satisfaction. Although most past research has found functional value to be significant (Gill et al., 2007), in this research the economic value was found to have a high significance in influencing customer satisfaction. However, a possible reason why economic value is highly significant is that respondents feel that prices and services rendered are important in influencing their purchase intentions in a convenience store. Nonetheless, the research findings indicate that presenting customers with a fair price is a significant part for customers. The customers who are price-perceptive have a preference to buy products at the best-value price. If it is simultaneous with customer satisfaction, then customers who patronise a convenience store will not perceive products purchased from the convenience store as highpriced products if they tend to derive satisfaction comparable to the products.

\subsubsection{Examining the role of customer satisfaction towards customer's loyalty and retention}

In this research, customer loyalty and retention was deliberated over from the perspective of customers' behavioural objective to constantly or progressively buy more in the present convenience shop, and their tendency to recommend the convenience shop to other individuals. This appraisal was confirmed as positive in previous studies (Zeithaml, Berry, and Parasuraman, 1996). However, satisfied customers have a propensity to have a superior usage intensity of a service than unsatisfied individuals (Bolton and Lemon, 1999; Ram and Jung, 1991); on the other hand, they are more likely to acquire stronger repurchase intent and to suggest the product/ service to their associates (Zeithaml et al., 1996). A fair number of studies have made known that customer satisfaction positively influences customer loyalty and retention (Bloemer, de Ruyter and Wetzels, 1999; Oliver, 1999; Zeithaml et al., 1996). This correlates with the finding of this research as shown in Table 11 that customer satisfaction is a positive and significant driver of customer loyalty and retention (Cronin et al., 2000; Fornell et al., 1996; Yang and Peterson, 2004). This general satisfaction has a strong positive effect on customer loyalty intents across an ample range of product as well as service groups (Gustafsson, 2005). It is a significant feature for a long-term relationship between a company and a consumer (Anderson and Srinivasan, 2003).

Conclusively, the research findings of the research seem to be in line with most scholars such as Sweeney and Soutar (2001), Wang et al. (2004) and William and Soutar (2000), who believed that CPV dimensions are significant in measuring customer satisfaction and in turn produce loyalty and retention; although these findings have been linked to brand only; therefore, as regards convenience stores, this research has tried to shed light on the extent to which each CPV dimension affects customer satisfaction in a convenience store and how it leads to loyalty and retention, thereby showing and explaining the objectives of the research and seeing that economic value is more significant for a convenience store customer than an emotional factor or social factor as price is what controls consumer perceived value. 


\subsection{Recommendation}

The following recommendations are made after critically analysing the data and arriving at certain findings. However, for convenience stores to increase their customer satisfaction as well as loyalty and retention:

1. It is important that convenience stores need to offer their customers the benefit of membership card. It is an effort to satisfy and retain their customers. Furthermore, it is also evidence that a membership card has encouraged customers to remain loyal. However, when a customer has a membership card, he/she has the possibility to get a special price discount and purchase points in contrast to the situation when he/she does not own a membership card. This can be done by aggregating the functional, conditional and emotional value of a convenience store, thereby maximising profit margin.

2. Convenience stores should be able to allocate resources for sales promotional tools such as price discounts, coupons, bonus packs as many scholars have found this medium to be highly significant in increasing sales (see: Little and Klein, 1983; Bawa and Shoemaker, 1987; Neslin, 1990).

3. Creating perceived value by placing more emphasis on functional, conditional as well as emotional features of convenience stores will create trust among their consumers, which can lead to revenue growth.

4. Product assortment is significant so as to provide a wide range of products for customers and also more focus should be on sales promotion so as to retain customers.

\subsection{Managerial Implications}

The finding of this study shows that improving social and economic values would develop customer satisfaction, loyalty and retention. Therefore, it is significant to highlight improving economic aspects of convenience stores. Perhaps a reasonable pricing strategy could add to customer satisfaction, loyalty and retention. This could result in an increase in sales.

\section{References}

Abu Bakar, A. (2014) 'Customer store loyalty in the context of customer perceived value in Saudi Arabia', Journal of contemporary research in business, Vol. 5, No. 12, pp. 442-460. Retrieved 29.09.2015 from http://journalarchieves36.webs.com/442-460apr14.pdf.

Abu Bakar, A., Al Ruwais, N. and Othman, A. (2013) 'Customer net value: A service gap perspective from Saudi Arabia’, Global journal of business research, Vol. 7, No. 4.

Anderson, J.C. and Narus, J.A. (1998), 'Business Marketing: Understand What Customers Value', Harvard Business Review, Vol. 76 No. 6, pp. 53-61.

Aliaga, M., and Gunderson, B. (2000) Interactive Statistics. Saddle River, pp. 3-15.

Bird, D. (2009) 'Questionnaire: The use of questionnaires for acquiring information on public perception of natural hazards and risk mitigation - a review of current knowledge and practice', Natural Hazards and Earth System Sciences. Retrieved 25.10.2015 from http://www.nat-hazards-earth-syst-sci.net/9/1307/2009/ nhess-9-1307-2009.pdf.

Bolton, R. and Drew, J. (1991) 'A multistage model of customers' assessments of service quality and value', Journal of consumer research, Vol. 17, pp. 375-384.

Burns, N. and Glove, S. (2003). Descriptive design. Research design and methodology. Retrieved 15.09.2015 from http://www.ais.utm.my/researchportal/files/2015/02/Example3-Res-Design.pdf.

Carpenter, J.M. (2008) 'Demographics and Patronage Motives of Supercenter Shopper in the United States', International Journal of Retail \& Distribution Management, Vol. 31 No. 1, pp. 5-16.

Dick, A.S. and Basu, K. (1994) 'Customer loyalty: toward an integrated framework', Journal of the Academy of Marketing Science, Vol. 22 No. 2, pp. 99-113.

Calabuig, F., Juan, N., Vicente Prado, G. and Ano, V. (2013), 'Effect of price increase on future intension of sport consumers', Journal of business research, Vol. 58 No. 7, pp. 1102-1118. 
Candan, B., Unal, S., Ercis A., (2013) 'Analysing the relationship between consumption values and brand loyalty of young people', European Journal of Research on Education, Special issue: Human resource Management, pp. 29-46.

Chang, C. and Dibb, S. (2012). 'Reviewing and conceptualising customer-perceived value', Marketing Review, Vol. 12 No. 3 pp. 253-274.

Chi, H., Yeh, H. and Tsai, Y. (2009), 'The Influences of Perceived Value on Consumer Purchase Intention: The Moderating Effect of Advertising Endorser', Journal of International Management Studies, Vol. 6 No. 1, pp. 2-6.

Chi, T. and Kilduff, P. (2011) 'Understanding consumer perceived value of casual sportswear', Journal of Retailing and Consumer Services, Vol. 18 No. 5, pp. 422-429.

Christine, H., Wim, V. and John, V. (2011) 'European consumer's perceived importance of qualifying and disqualifying nutrients in food choices, Food Quality and Preferences, Vol. 22 No. 6, pp. 550-558.

Collins, H. (2010). Creative Research: The Theory and Practice of Research for the Creative Industries. London: AVA Academy. Retrieved 29.08.2015 from https://books.google.com.my/books?id=oyAwg8qSyJYC\&pg $=\mathrm{PA} 124 \& \mathrm{dq}=\mathrm{key}+$ definition + for + data + collection + tool + through + questionnaire $\&$ hl $=$ en $\&$ sa $=\mathrm{X} \& \mathrm{ei}=0 \mathrm{GxD}$ Va3bCYOIuwTT3IH4CQ\&ved=0CC8Q6AEwBA\#v=onepage\&q=key\%20definition $\% 20$ for $\% 20$ data $\% 20$ collection $\% 20$ tool $\% 20$ through $\% 20$ questionnaire $\& \mathrm{f}=$ false.

Desmet, P. (2014) 'How retailer money-back guarantees influence consumer preferences for retailers versus national brands', Journal of business research, Vol. 67 No. 9, pp. 1971-1978.

Driscoll, D. (2011). Introduction to Primary Research: Observations, Surveys, and Interviews. Pavel: Parlor Press. Retrieved 10.08.2015 from http://www.parlorpress.com/pdf/driscoll--introduction-to-primary-research.pdf.

Ehsani, Z and Hashim, N. (2015). 'Effect of customer perceived value on customer relationship management performance', International Journal of Science, Commerce and Humanities, Vol. 3 No. 1, pp. 139-146. Retrieved 22.09.2015 from http://www.ijsch.com/journaluk/images/frontImages/EFFECT_OF_ CUSTOMER_PERCEIVED_VALUE_ON_CUSTOMER_RELATIONSHIP_MANAGEMENT_ PERFORMANCE.pdf.

Gale, B.T., Clutterbuck, D. and James, D. (1996) 'Customer Value- the Next Step?' Customer Service Management, Vol. 12, pp. 18-23.

Gill, D., Byslma, B.and Ouschan, R. (2007). 'Customer perceived value in a cellar door visit: the impact on behavioural intentions’, International Journal of Wine Business Research, Vol. 19 No. 4, pp. 257-275.

Goldman, A., Krider, R. and Ramaswami, S. (1999) 'The persistent competitive advantage of traditional food retailers in Asia: Wet market's continued dominance in Hong Kong', Journal of Macromarketing, Vol. 19, pp. 132-139.

Gratton, C. and Jones, I. (2004). Research Methods for Sport Studies. London: Routledge. Retrieved 08.08.2014 from https://books.google.com.my/books?id=fXwy_o0e9psC\&pg=PA20-IA8\& $\mathrm{dq}=$ primary + research + methods + for + research $\& \mathrm{hl}=$ en $\& \mathrm{sa}=\mathrm{X} \& \mathrm{e} \mathrm{i}=\mathrm{Ru} 9 \mathrm{BVbeEFNSVuATq}-$ IHABA\&ved=0CDUQ6AEwBQ\#v=onepage\&q=primary\%20research\%20methods\%20for\%20 research\&f=false.

Hair, J.F. (2003). Research Design and Methodology, [Online]. Retrieved 18.09.2015 from http://shodhganga. inflibnet.ac.in/bitstream/10603/7670/9/09_chapter\%204.pdf.

Holbrook, M.B (1999) Introduction to consumer value: A Framework for analysis and research. London: Routlege.

Khalifa A.S. (2004) 'Customer value: a review of recent literature and an integrative configuration', Management Decision, Vol. 42 No. 5, pp. 645-666.

Kotler, P. and Armstrong, G. (2013) Principles of Marketing (15th Global Edition). Pearson.

Loureiro, S., Sardinha, D. and Reijnders, L. (2012) 'The effect of corporate social responsibility on consumer satisfaction and perceived value', Journal of Cleaner Production, Vol. 37 No. 172, pp. 1-2. Retrieved 27.07.2015 from http://dx.doi.org/10.1016/j.jclepro.2012.07.003.

Ledden, L., Kalafatis, S.P. and Mathioudakis, A. (2011) 'The idiosyncratic behaviour of service quality, value, satisfaction, and intention to recommend in higher education: an empirical examination', Journal of Marketing Management, Vol. 27 No. 11, pp. 1232-1260.

Liljander, V. and Strandvik, T. (1995) 'The nature of customer relationships in services', Advances in Services Marketing and Management, Vol. 4, pp. 78-82.

Monroe, K.B. and Krishnan, R. (1985). 'The Effect of Price on Subjective Product Evaluations', in: Jacoby, J. and Olson, J. (Eds), The Perception of Merchandise and Store Quality. Lexington, MA: D. C. Heath.

McCarthy, E.J. (1971). Basic Marketing: A Managerial Approach (4th ed.). Homewood, Ill: R.D. Irwin.

Marketta, R. (2012) 'Product quality and value from consumer perspective - An application to wooden products', Journal of Forest Economics, Vol. 18 No. 2, pp. 70-77.

Mugera, W. (2013) Non-probability sampling techniques, [online]. Retrieved 09.09.2015 from https://learning.uonbi. ac.ke/courses/LDP603/work/assig_2/Non-probability_sampling_techniques_assignment_1.pdf.

Novo, J. (2011) Customer Retention through behavioural modelling, Drilling Down, pp 5-18. 
Pan, Y., Gao, L. and Wang, F. (2009) 'The effects of perceived value on consumer's purchase behavior in China: Evidence from mobile phone market in Shanghai', Journal of Beijing University of Posts and Telecommunications, Vol. 11 No. 2, pp. 46-51.

Panda, T. (2007) Marketing Management. India: Excel Books.

Parasuraman, A. and Grewal, D. (2000) 'The impact of technology on the quality-value-loyalty chain: A research agenda', Journal of Academic of Marketing Science, Vol. 28, pp. 168-174.

Parasuruman, A. (1997) 'Reflections on gaining competitive advantage through customer value', Journal of the academy of marketing science, Vol. 25, pp. 154-161.

Park, J. and Jang, S. (2014) 'Why do customers switch', International Journal of Hospitality Management, Vol. 37, pp. $159-170$.

Peng, L and Liang, S. (2013) 'The effects of consumer perceived value on purchase intention in e-commerce platform: a time-limited promotion perspective', Journal of Joint Author Workshop, Vol. 1. Retrieved 01.09.2015.

Roig, J.G.F., Garcia, J.S., Tena, M.A.M. and Monzonis, J.L. (2006) 'Customer perceived value in banking services', International Journal of Bank Marketing, Vol. 24 No. 5, pp. 266-283.

Salo, M., Olsson, T., Makkonen, M., Hauamaki, A. and Frank, L. (2013) 'Consumer value of camera-bases mobile interaction with the real world', Pervasive and Mobile Computing, Vol. 9 No. 2, pp. 258-268.

Saunders, M., Lewis, P. and Thornhill, A. (2003) Research methods for business students (1st ed). Harlow, England: Prentice Hall.

Sanchez, J., Callarisa, L.J., Rodriguez, R.M. and Moliner, M.A. (2006) 'Perceived value of the purchase of a tourism product', Tourism Management, Vol. 27 No. 4, pp. 8-16.

Sanchez-Fernandez, R., Iniesta-Bonillo, M. and Holbrook, M.B. (2009) 'The conceptualization and measurement of customer value in services', International Journal of Marketing Research, Vol. 15, pp. 93-113.

Schmenner, R.W. (1986), 'How can service businesses survive and prosper', Sloan Management Review, Vol. 27 No. 3, pp. 21-32.

Sheth, J.N., Newman, B.I. and Gross, B.L. (1991) 'Why We Buy What We Buy: A Theory of Consumption Values', Journal of Business Research, Vol. 22 No. 2, pp. 159-170.

Singh, H. (2006), 'The Importance of Customer Satisfaction in relation to customer loyalty and retention', UCTI.WP. Retrieved 06.05.2006 from http://www.van-haaften.nl/images/documents/pdf/The\%20Importance\%20of\%20 Customer\%20Satisfaction\%20in\%20Relation\%20to\%20Customer\%20Loyalty\%20and\%20Retention.pdf.

Smith, J. B. and Colgate, M. (2007) 'Customer value creation: a practical framework', The Journal of Marketing Theory and Practice, Vol. 15 No. 1, pp. 7-23.

Sweeney, J.C. and Soutar, G.N. (2001) 'Consumer perceived value: The development of a multiple item scale', Journal of Retailing, Vol. 77, pp. 203-220.

Sweeney, J. and Swait, J. (2008) 'The effects of brand credibility on customer loyalty', Journal of Retailing and Consumer Services, Vol. 15, pp. 179-193.

Tabassum N., Zafar, Z., Ali, A., Alam, A. and Ali M. (2013) 'The Effect of Value Perception on Customer Loyalty and Satisfaction', IOSR Journal of Business and Management, Vol. 12 No. 6, pp. 62-69. Retrieved 04.10.2016 from http://iosrjournals.org/iosr-jbm/papers/Vol12-issue6/G01266269.pdf

Ulaga, W. and Chacour, S. (2001) 'Measuring customer perceived value in business markets'. Industrial Marketing Management, Vol. 30, pp. 525-540.

Vera, J. and Trujillo, A. (2013) 'Service quality dimensions and superior customer perceived value in retail banking', Journal of Retailing and Consumer Service, Vol. 20 No. 6, pp. 579-586

Westbrook, R.A. and Oliver, R.L. (1991) 'The dimensionality of consumption emotion patterns and consumer satisfaction', Journal of Consumer Research, Vol. 18, pp. 84-91.

Woodruff, R.B. (1997) 'Customer value: The next source for competitive advantage', Journal of the Academy of Marketing Science, Vol. 25, pp. 139-153.

Xiucheng, F. and Yunlai, Z. (2006) 'A study on emotional impact mechanism of impulsive purchase', Social Scientist, Vol. 118 No. 2, pp. 148-151.

Yang, K. (2006) The Effects of Consumer Perceived Value and Subjective Norm on the Adoption of Mobile Data Services: A Crosscultural Comparison of American and Korean Consumers, PhD diss., University of Tennessee, http://trace.tennessee.edu/utk_graddiss/2049.

Young, D.L., Goodie, A.S., Hall, D.B., and Wu, E. (2012) 'Decision making under time pressure, modeled in a prospect theory framework', Organizational Behaviour and Human Decision Processes, Vol. 118 No. 2, pp. 179-188.

Yu Wu, L., Yang, K., Chen, P., Cheng, S. (2014) 'Perceived value, transaction cost, and repurchase-intension in online shopping', Journal of Business Research, Vol. 67, pp. 2768-2776. Retrieved 24.06.2015 http://isiarticles. com/bundles/Article/pre/pdf/17994.pdf.

Yu, Y. and Dean, A. (2001) 'The Contribution of Emotional Satisfaction to Consumer Loyalty', International Journal of Service Industry Management, Vol. 12 No. 3, pp. 1-17. Retrieved 21.10.2015 from http://www. 
ponzoa.com/directorios/otra_bibliografia_recomendada/The $\% 20$ contribution $\% 20$ of $\% 20$ emotional $\% 20$ satisfaction $\% 20$ to $\% 20$ consumer $\% 20$ loyalty.pdf.

Yusuf, J., Singh, G. and Razak, R. (2013) 'Purchase intension of environment-friendly automobile', Social and Behavioural Sciences, Vol. 85, pp. 400-410.

Ziethaml, V.A., (1988) 'Consumer perception of price, quality, and value: a means-end model and synthesis of evidence', Journal of Marketing, Vol. 52, pp. 2-22. 